\title{
The effects of COVID-19 litter on animal life
}

\author{
Auke-Florian Hiemstra ${ }^{1,2,3, * *}$, Liselotte Rambonnet ${ }^{2,3, *}$, Barbara Gravendeel $^{1,4}$ and \\ Menno Schilthuizen ${ }^{1,2}$ \\ ${ }^{1}$ Naturalis Biodiversity Center, 2333 CR Leiden, The Netherlands \\ ${ }^{2}$ Institute of Biology, Leiden University, 2333 BE Leiden, The Netherlands \\ ${ }^{3}$ De Grachtwacht, 2312 GP Leiden, The Netherlands \\ ${ }^{4}$ Institute for Water and Wetland Research (IWWR), Radboud University, 6525 AJ Nijmegen, The \\ Netherlands \\ Submitted: October 24, 2020. Final revision received: February 2, 2021. Accepted: February 9, 2021
}

\begin{abstract}
During the COVID-19 pandemic, Personal Protective Equipment (PPE) is massively used, resulting in a new wave of litter: protective face masks and gloves. Here we present the first case of a fish entrapped in a medical glove, encountered during a canal clean-up in Leiden, The Netherlands. We also report the first cases of birds using medical face masks as nesting material, which were also found in the Dutch canals. To place these new findings in context, we collected online reported interactions of animals with PPE litter, since the start of the pandemic. This resulted in the first overview of cases of entanglement, entrapment and ingestion of COVID-19 litter by animals and the use of it as nesting material. We signal COVID-19 litter as a new threat to animal life as the materials designed to keep us safe are actually harming animals around us. To understand the full scale of this problem, we welcome anyone to contribute to our overview by submitting their observations online at www.covidlitter.com. To further prevent PPE litter, it is recommended that, when possible, reusable alternatives are used.
\end{abstract}

\section{Keywords}

Bird nest; entanglement; entrapment; face mask; plastic pollution; PPE

\section{Introduction}

After the outbreak of the COVID-19 virus was first identified in Wuhan, China, in December 2019, the World Health Organization officially declared the virus a pandemic on 11 March 2020 (WHO, 2020). During the past months the pandemic has resulted in almost 90 million confirmed cases and almost two million deaths

\footnotetext{
*) Corresponding author; e-mail: aukeflorian.hiemstra@ naturalis.nl

**) These authors contributed equally to this work.
} 
globally as of early January 2021 (JHUM, 2020). While we have seen reductions in air pollution (Chen et al., 2020; Dutheil et al., 2020), $\mathrm{NO}_{2}$ emissions (NASA, 2020), and $\mathrm{CO}_{2}$ emissions (Myllyvirta, 2020), plastic pollution seems to be increasing (Fadare \& Okoffo, 2020; Silva et al., 2021). To protect humans against this virus, personal protective equipment (PPE) is being used more frequently. China, for example, increased face mask production by $450 \%$ in just one month (Bown, 2020). It is estimated that we have a monthly use of 129 billion face masks and 65 billion gloves globally (Prata et al., 2020). Similar to the usage of other single-use plastic items, this also means an increase of PPE littering our environment (Fadare \& Okoffo, 2020). PPE litter, also referred to as COVID-19 litter, mainly consists of single-use (usually latex) gloves and single-use face masks, consisting of rubber strings and mostly polypropylene fabric. Three months after face masks became obligatory in the UK, PPE items were found on 30\% of the monitored beaches and at $69 \%$ of inland clean-ups by the citizen scientists of the Great British Beach Clean (Riglen, 2020). Even on the uninhabited Soko Islands, Hong Kong, already 70 discarded face masks were found on just a 100-meter stretch of beach (Kassam, 2020). A growing public concern about PPE litter became apparent during March and April 2020, as a Google News search on 'PPE' and 'litter' showed a sudden increase in news articles (Canning-Clode et al., 2020). As a response to the increase of COVID-19 litter, many states in the USA have raised the fines for littering PPE, sometimes up to $\$ 5500$ as in Massachusetts (O'Laughlin, 2020).

The \#glovechallenge, in which people shared their observations of gloves and face masks (fig. 1), resulted in more than 11000 photos of COVID-19 litter from all over the world (Cardona, 2020). A Dutch COVID-19 litter project reported 6347 photos of gloves or face masks littering The Netherlands during the months of May and June (Groot, 2020). Initially, these products were mainly found in close vicinity to supermarkets and healthcare institutions, but when face masks became compulsory in public transport, they were also increasingly being found near bus, tram, and train stations. By now the use of face masks is mandatory or highly recommended in many countries (Sylva et al., 2020). As a consequence, the increase in production and consumption of PPE litter inevitably leads to interaction with animal life.

While the percentage of COVID-19-related litter may be small in comparison with packaging litter (Groot, 2020), it can be seen as a typical example of our single-use society. Both masks and gloves pose a risk of entanglement, entrapment and ingestion, which are some of the main environmental impacts of plastic pollution (Ryan, 2018; Kuhn \& van Franeker, 2020). Plastic can have enormous impacts on animals, some direct, others indirectly. An entanglement, for example, can be acute, resulting in immediate death by suffocation or drowning, or chronic, meaning it may exhaust the animal, restrict feeding to the point of starvation or result in strangulations, wounds, infections or cause amputations (Butterworth et al., 2012). Face masks littering the environment could also be an emerging new source of microplastics (Fadare \& Okoffo, 2020), but the masks already cause harm prior to degrading. The Iranian cartoonist Alireza Pakdel drew a predictive cartoon 




Figure 1. Compilation of 256 images of PPE litter from Vista, CA, USA. Photograph by Janis Selby Jones.

regarding the effects of COVID-19 litter at the start of the pandemic, showing a fish entangled in a face mask facing another fish entrapped in a glove (Pakdel, 2020). Such situations have by now been found in real life - and are presented here. This is the first overview of case studies of the increasing threat of entrapment, entanglement, ingestion of PPE and its inclusion as nesting material by birds.

\section{Methods}

Volunteers participating in the Plastic Spotter canal clean-ups collect floating litter using canoes in Leiden, The Netherlands (Rambonnet et al., 2020). Their encounter of a fish entrapped in a latex glove sparked our interest, which was fueled further by the find of face masks and gloves in bird nests. To place these observations into 
context we collected all observations of interactions of animal life with COVID-19 litter reported online since the start of the pandemic. For this, we used both Google web search and Google image search, as a method to rapidly collect sightings (Leighton et al., 2016). Search terms that were used, in combination, are: 'litter', 'waste', 'PPE', 'COVID', 'COVID-19', 'corona', 'face mask', 'glove', 'entanglement', 'entangled', 'entrapment', 'entrapped', 'ingestion', 'ingested', 'bird nest'; both in English and in Dutch. These search terms, used as hashtags, were also used to explore social media platforms Twitter, Facebook and Instagram for observations. If supporting information on the observation was lacking in the articles and posts we found, we traced back the origins of the photos and articles, using reverse image search or by searching the names of the observer, to collect any further information on the locality, date, observer, and any other details. When these details could not be found online, we tried to contact the observers and reporters when possible.

\section{Presentation of the concerns}

The first case of the impact of COVID-19 litter discussed here originates from Leiden, The Netherlands. Already two weeks after the first Dutch case of COVID-19, a face mask was found as litter in the Leiden canals (pers. obs.). Since then, each weekly canal clean-up resulted in multiple face masks and gloves, sometimes over 100 items. At the time of writing, so far many hundreds of face masks and gloves have been found, and counting.

It is known that riverine ecosystems are directly affected by plastic pollution (van Emmerik \& Schwarz, 2020). The canals of Leiden harbor not only hotspots of plastic (Tasseron et al., 2020), but also 22 species of fish (van Aarsen, 2018; Verkade, 2018), some of which are protected by national laws and European regulations (MEZ, 2015; MLNV, n.d.). The first evidence that freshwater fish suffer from the recent wave of PPE litter is presented here, with the find of a dead perch (Perca fluviatilis) entrapped in a latex glove, with only its tail sticking out (fig. 2). The fish was found in the Oude Vest, Leiden, by citizen scientists during a Plastic Spotter canal clean-up on the 2nd of August 2020, making it the first victim of COVID19 litter from The Netherlands. The glove was partially ruptured around the base of the thumb, where the fish was entrapped, which could be the result of a struggle. The spiny dorsal fins might have prevented a backward exit. When found, the glove was partly inside-out, meaning that it had been worn before being discarded. As the glove could potentially be contaminated with the COVID-19 virus, precautions were taken by the volunteers during the handling of the specimen and the PPE litter it was entrapped in. The perch, still in its glove, is stored in ethanol as part of 'De Grachtwacht' collection located in Leiden, The Netherlands (GW9899-1E). Two years previously, the first fish entrapped in a glove near Tossa de Mar, Spain, was a widely shared news story (Regen, 2018). The polyethylene glove, meant for food preparation, became a classic example of the negative effects of plastic in our oceans. The newly found perch entrapped in a medical latex glove, however, shows 


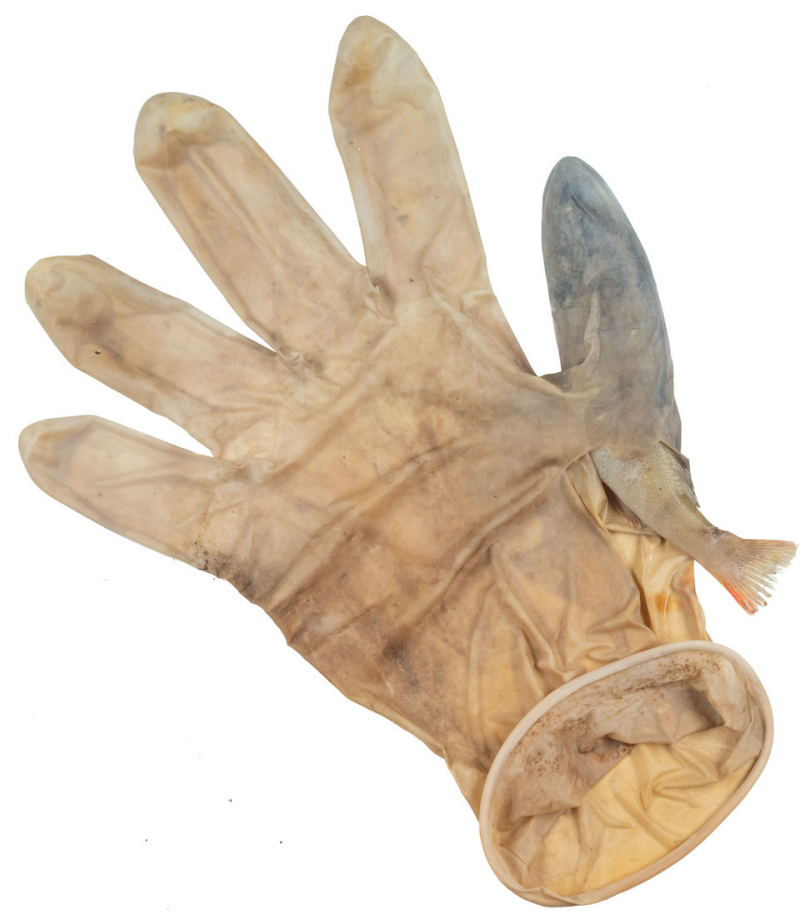

Figure 2. An entrapped perch (Perca fluviatilis) in a PPE glove (GW9899-1E), found during a Plastic Spotter clean-up in the canals of Leiden, The Netherlands. Photograph by Auke-Florian Hiemstra.

that plastic litter also impacts the lesser-studied freshwater ecosystems and that the new wave of PPE latex gloves littering our environment could make entrapments like these more frequent in the future.

However, interactions with COVID-19 litter are not always directly negative, as the use of plastic in nest construction is becoming more common (Jagiello et al., 2019). Birds now have also started to include COVID-19 litter into their nests. To our knowledge, we here present the first cases of the incorporation of medical face masks into bird nests. This behavior was firstly seen by a common coot (Fulica atra), a species known for its anthropogenic nests (Hiemstra et al., subm.), breeding on the Keizersgracht, Amsterdam, The Netherlands on the 3rd of June 2020 (pers. obs.). This face mask was later preserved in the Grachtwacht collection (GW9792-2). A nest made by common coots near the Beestenmarkt, Leiden, The Netherlands, showed both a medical face mask and a latex glove, and was collected on the 6th of September 2020 (pers. obs.; GW9792-3 and GW9792-4) (fig. 3). Gloves were also used as nesting material by sparrows (Passer sp.) in a residential area in Warsaw, Poland (Szulkin, 2020). Even packaging of pocket tissues was incorporated into coot nests in spring 2020 (pers. obs.; GW9792-5). Since sniffing is a symptom of COVID-19, this unlikely nest item may be pandemic-related as well. 

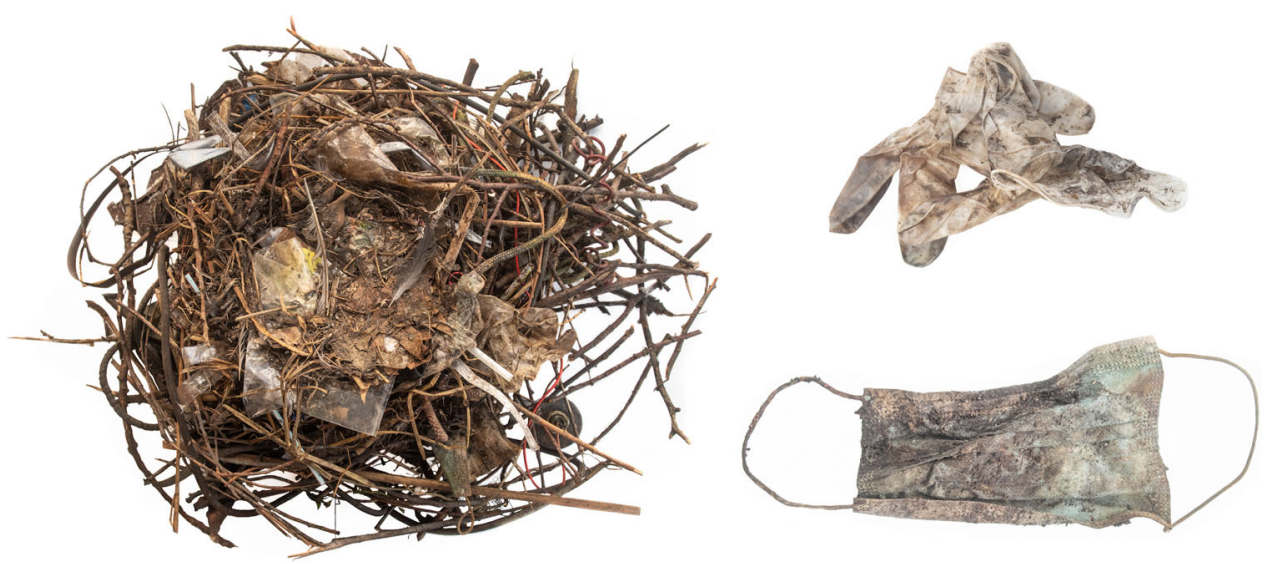

Figure 3. Nest of common coot (Fulica atra) partly built with face mask (GW9792-3) and glove (GW9792-4). Nest located at the Beestenmarkt, Leiden, The Netherlands, collected on the 6th of September 2020. Photograph by Auke-Florian Hiemstra.

Our observations may have been the first Dutch cases, yet the first reported victim of COVID-19 litter globally, to our knowledge, was an American robin (Turdus migratorius; Denisuk, 2020). This bird appears to have died after becoming entangled in a face mask at Chilliwack, BC, Canada, on the 10th of April 2020 (pers. comm. Sandra Denisuk; fig. 4). After that, a young gull (Larus sp.) was found walking with a face mask tangled around its legs in Chelmsford, Essex, UK (RSPCA Essex South, 2020). It had struggled with the mask for two weeks and its limbs and

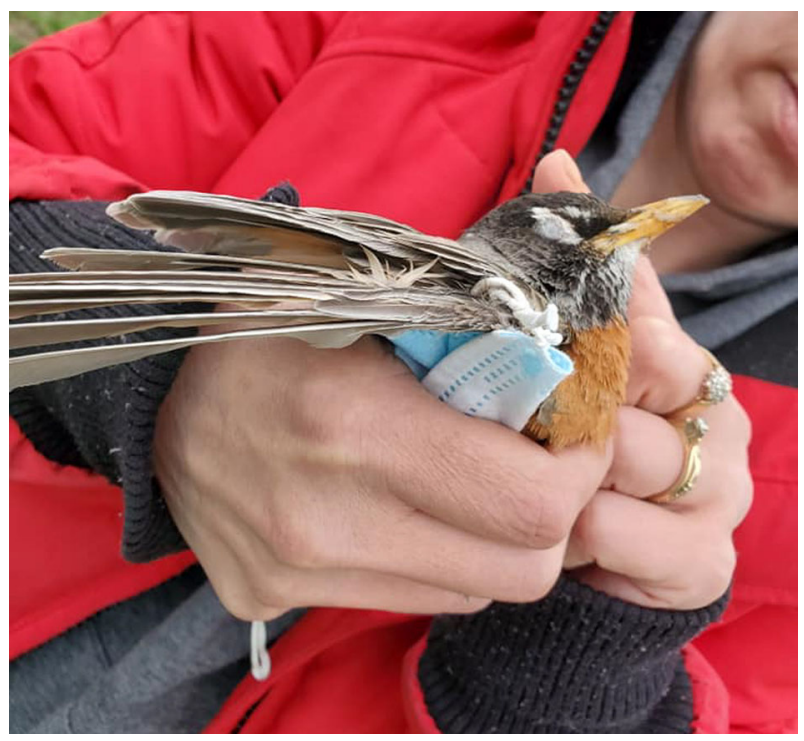

Figure 4. First victim of COVID-19 litter, an American robin (Turdus migratorius) entangled in a face mask at Chilliwack, BC, Canada on the 10th of April 2020. Photograph by Sandra Denisuk. 
joints were swollen, but it recovered in the South Essex Wildlife Hospital. A juvenile peregrine falcon (Falco peregrinus) on the Yorkshire coast, UK, with its talons entangled in a face mask, eventually managed to free itself (BBC, 2020a). Cygnets from a mute swan (Cygnus olor) from Lake Bracciano, near Rome, Italy, were observed with face masks around their beak (wwitaly, 2020), and a mallard (Anas platyrhynchos) with a mask hanging around its neck, seen in Casentino, Italy, was referred to by local media as "The duck unable to take off the mask" (ArezzoNotizie, 2020). A recent find of a dead gull in Rotterdam, The Netherlands, which was hit by a car, also had a face mask entangled around its legs. Although this entanglement may not have been the cause of death, it may have weakened the bird as a chronic entanglement, prior to the car-collision (Kompanje, 2021). The bird, together with its face mask, has been preserved in the Natural History Museum of Rotterdam (NMR 9989-172803).

However, not only birds are affected by face masks. While bats already suffer from roost destruction because they have been associated with the start of the COVID-19 outbreak (Shereen et al., 2020; Rocha et al., 2020), they also face the risk of entanglement in PPE litter. A serotine bat (Eptesicus serotinus) was found in Nijmegen, The Netherlands, entangled in two face masks (van Otterlo, 2020). A red fox (Vulpes vulpes), entangled in a face mask, and a European hedgehog (Erinaceus europaeus), entangled in a glove, were reported in the UK (BBC Breakfast, 2020). A hedgehog entangled in a face mask was found in The Netherlands (Egelopvang het Stekeltje, 2020). Also, a checkered pufferfish (Sphoeroides testudineus), entangled in a face mask, was found dead during a clean-up at Pace Picnic Island, west of Miami Beach, USA (Clean this beach up, 2020). Two shore crabs (Carcinus maenas) were encountered in lake Étang de Berre, France, of which one was found deadly entangled in a face mask, while another entangled crab was walking around with a face mask (Opération Mer Propre, 2020a). A common octopus (Octopus vulgaris) in the sea near Cannes, France, was filmed hiding under a face mask. "Even the octopus protects himself against Covid 19" was the description below the video on YouTube (Opération Mer Propre, 2020b; CGTN, 2021).

COVID-19 litter is also ingested by animals, as the find of a Magellanic penguin (Spheniscus magellanicus) in Brazil illustrates (Penza, 2020). The stomach of this animal, found on Juquehy Beach in São Sebastião, north of São Paulo, revealed an ingested face mask. Multiple long-tailed macaques (Macaca fascicularis) were seen chewing on a face mask in Genting Sempah, Malaysia (Getty Images, 2020). Young gulls (Laridae sp.) have also been observed fighting over a face mask on Weymouth beach, UK, as they were hunting for food, and one flying away with it in its beak (Klein, 2020). Young gulls carrying a face mask were also observed at the port of Dover, and at the coast of Weston-super-Mare in the UK (Reuters, 2020; Simmons, 2020). Ingestions of COVID-19 litter have also been seen in several domestic animals like a cat (Felis catus) (ACCT Philly, 2020) and four dogs (Canis lupus familiaris) (Defina, 2020; Kaur, 2020; University of Glasgow, 2020; van Gerwen, 2021). Even a six-year-old child ingested parts of a presumed blue face 
mask, accidentally baked into a McDonalds chicken nugget (BBC, 2020b). All the above interactions of animals with PPE litter can be found summarized in table 1 .

\section{Conclusions}

This is the first overview of reported cases of entanglement, entrapment, ingestion, and the use of COVID-19 litter as nesting material. Although the actual number of cases will be much higher than the number of cases found (Laist, 1997) we already signal COVID-19 litter as an emerging threat to animals. PPE litter has already been found in terrestrial, freshwater and marine ecosystems. Also, its impact is observed in all of these habitats, by both vertebrates and invertebrates, ranging from birds and mammals to fishes and crabs. However, to fully understand the scope of the impact of PPE litter, more research is needed.

As we only searched articles in English and Dutch and found mainly cases from the UK, USA and The Netherlands, we expect that more examples of interactions between animals and PPE litter can be found from sources in other languages. For example, using reverse image search on a photo encountered on social media, we traced back the source of the report of an entangled bird to a local Italian newspaper (ArezzoNotizie, 2020). This was also done for a photo of an entangled crab, which was encountered on an English website (CGTN, 2021). We were able to trace it back to French social media pages where we also encountered another observation of an entangled crab and the octopus hiding under a face mask (Opération Mer Propre, 2020a, b). To understand the full scale of the problem, we encourage anyone to add their observations to our regularly updated overview, accessible online at www.covidlitter.com. Especially litter pickers, animal rescue centers, bird watchers and nature photographers have proven to play a vital role in observing and sharing interactions of animals with PPE litter, and we encourage them to keep reporting any new observations.

As we deal with a recently introduced and relatively easily recognizable type of litter, monitoring its impact on animals can provide us with a unique insight of the impact such a type of single-use plastic can have. The pandemic is not over yet, and the amount of PPE used may only increase, and will continue to threaten wildlife way beyond the time access to a vaccine becomes available. In addition to this, the already littered items will degrade into micro- and nanoplastics and stay in the environment for hundreds of years (Fadare \& Okoffo, 2020; Kassam, 2020). To better understand the scope of the impact of face masks and gloves, it is also important to monitor PPE litter.

To achieve this goal, we acknowledge the importance of citizen science initiatives that collect data on litter, for example during beach cleans (Rambonnet et al., 2019). We encourage citizen science efforts to increase the monitoring of PPE litter and we recommend updating the standardized method for monitoring beach litter, the OSPAR guideline (OSPAR, 2010; Silva et al., 2020). We believe that separate categories for latex gloves and face masks should be added. The Great British Beach 


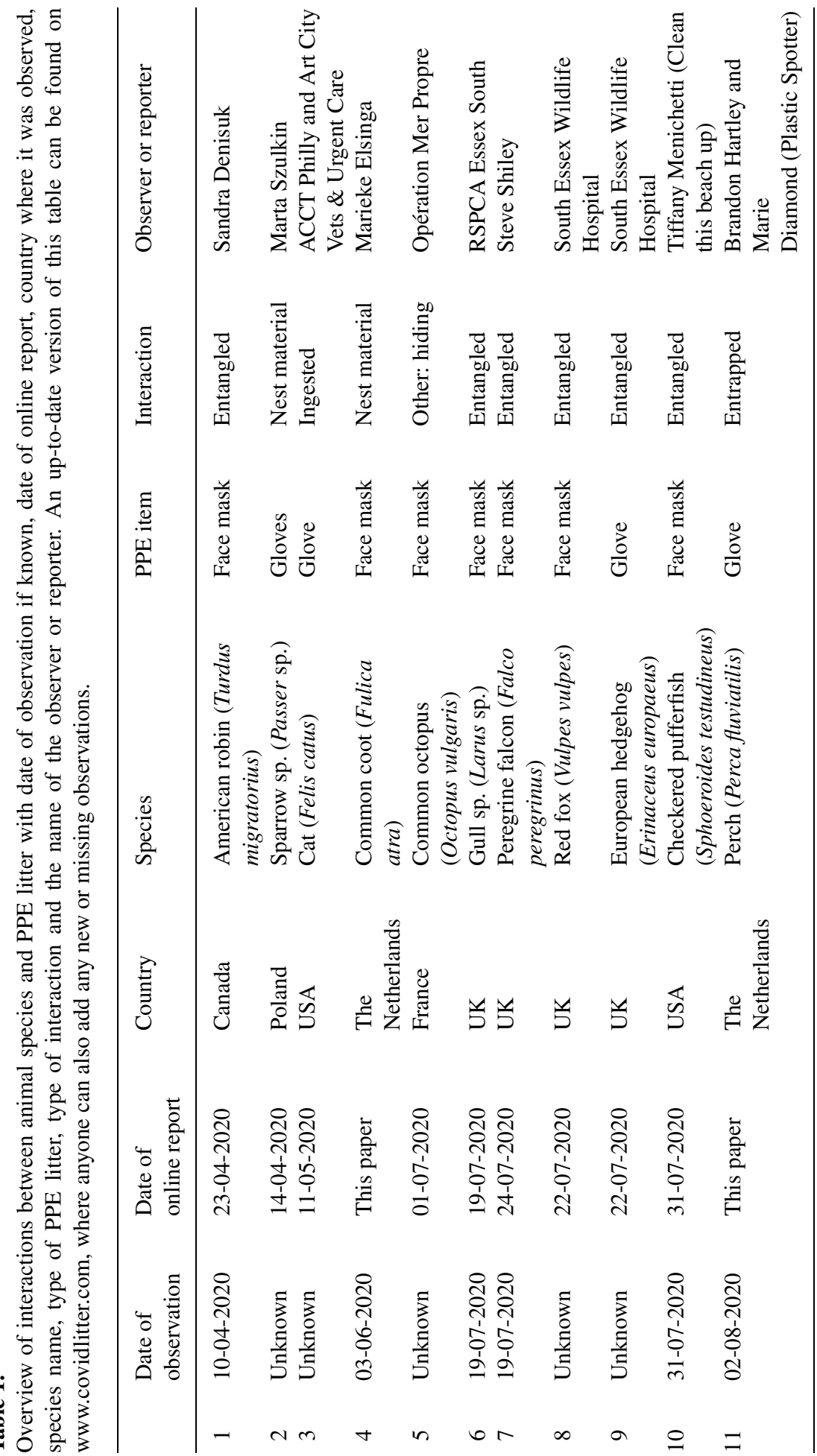






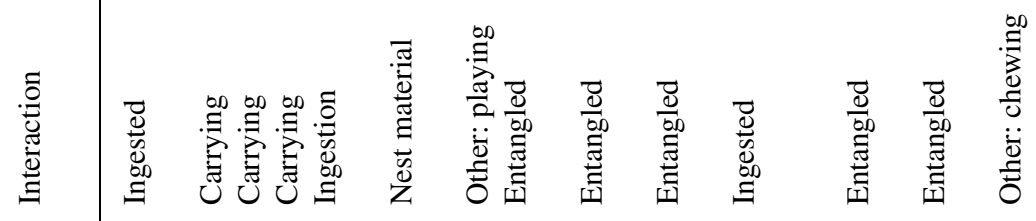

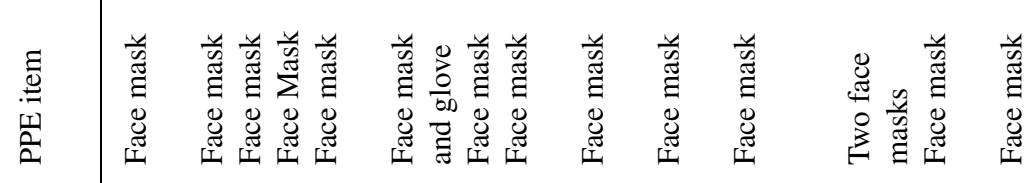

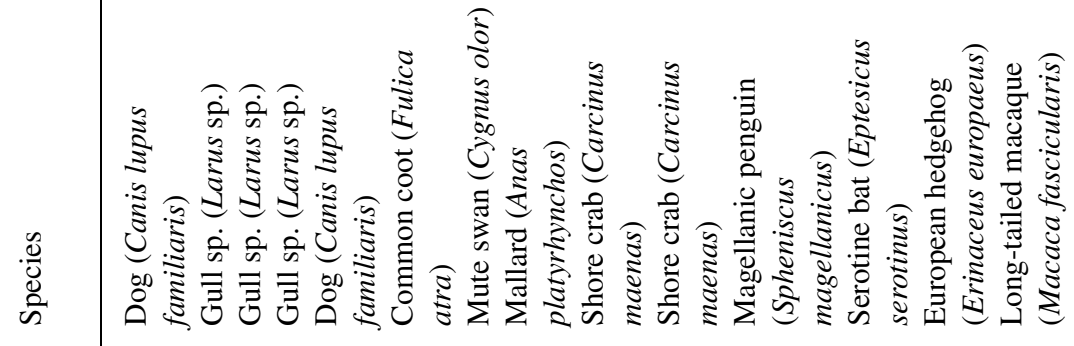

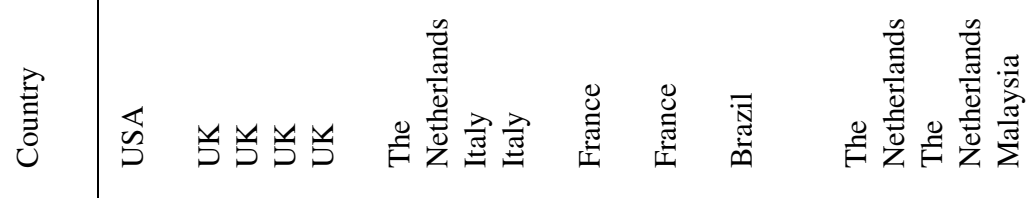

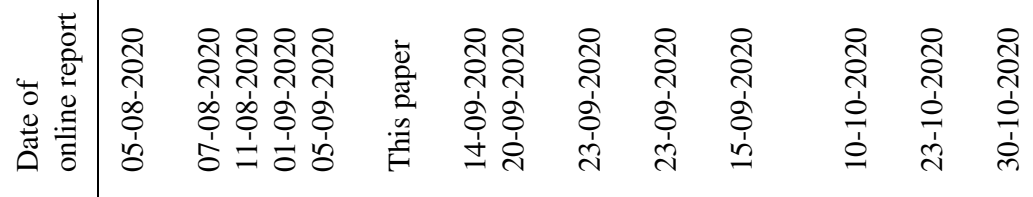

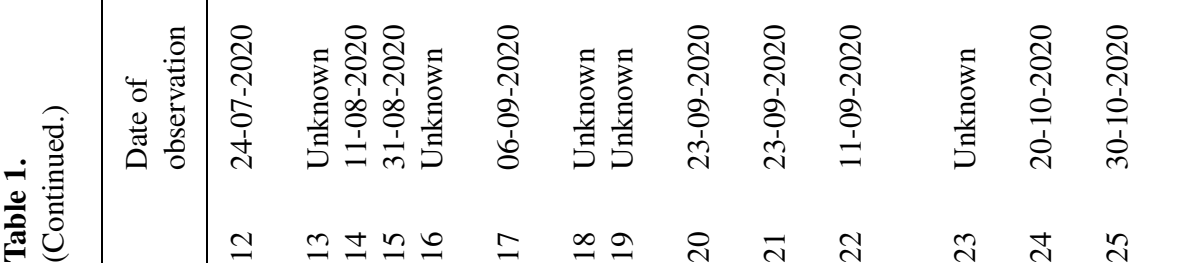




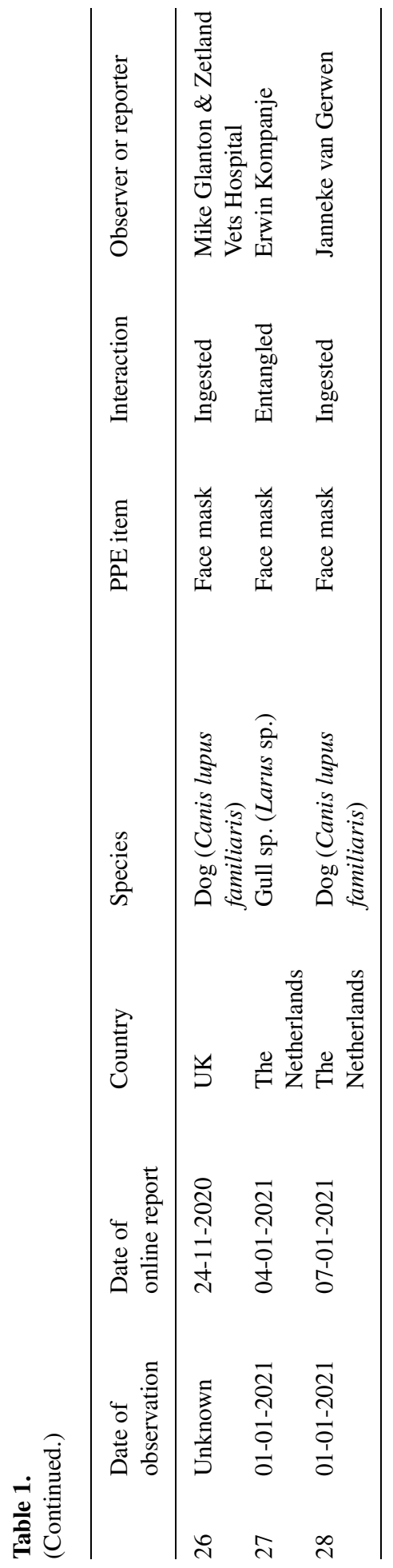


Clean also asked their volunteers to monitor this type of litter in September 2020, which helped to map the extent of PPE litter in the UK (Matthews, 2020). As this material is a potential biohazard precautions should be taken during clean-ups as COVID-19 can survive up to three days on for example plastic surfaces (van Doremalen et al., 2020). Litter monitoring campaigns help us understand the scope of this new category of problematic litter.

Other initiatives call on people to cut up disposable gloves and snip the straps on face masks before discarding them, as this could help prevent animals from getting entangled (RSPCA, 2020; Toliver, 2020). A similar strategy is being used for plastic six-pack rings, which should also be cut up before being discarded to prevent entanglements (Stachowitsch, 2019). In addition, it is recommended to take the impact of PPE litter on the environment into account when developing PPE products (Schweitzer et al., 2018).

The PPE products that are designed to keep us safe are actually harming animals around us. It is striking that all the reported findings of entanglement, entrapment, ingestion, and incorporation of PPE into nests so far involved single-use products. Switching to reusables will result in a 95\% reduction in waste, according to the UCL Plastic Waste Innovation Hub (2020). To minimize the amount of COVID-19 litter and its effect on nature, we urge that, when possible, reusable alternatives are used. People may suffer from the coronavirus pandemic, but nature is getting sick of our plastic.

\section{Acknowledgements}

Thanks to Jaap Bierman, Daniël Siepman, Janis Selby Jones, Sandra Denisuk, Mirjam van Otterlo, Marieke Elsinga, Sonja Bierenbroodspot, Jeroen Goud, Charles Fransen, Citizen Science Lab, the citizen scientists from the Plastic Spotter canal clean-ups, and all litter pickers, animal rescue centers, bird watchers and nature photographers who monitor and minimize the effect of COVID-19 litter.

\section{Author contributions}

Auke-Florian Hiemstra: Conceptualization, Investigation, Writing - Original Draft, Photography. Liselotte Rambonnet: Conceptualization, Investigation, Writing Original Draft. Barbara Gravendeel: Writing Review \& Editing, Supervision. Menno Schilthuizen: Writing Review \& Editing, Supervision.

\section{Funding}

The fieldwork that made this paper possible was funded by grants from Leiden University and Leiden Municipality to De Grachtwacht and its Plastic Spotter project. While working on this manuscript, the first author Auke-Florian Hiemstra was financially supported by a PhD grant from Albert Heijn. 


\section{References}

ACCT Philly (2020, May 11) Please read, though this is a sad update, it's important: when Foxxy came to us, she was emaciated and dehydrated [Image attached] [Status update]. Facebook. https:// www.facebook.com/acctphilly/photos/a.609611599091313/318765134620644/?type=3.

ArezzoNotizie (2020, September 20) Vergogna nell'Arno, l'anatra che non riesce a togliersi la mascherina. https://www.arezzonotizie.it/zone/casentino/pratovecchio-stia/foto-anatramascherina-arno.html.

BBC (2020a, July 24) Peregrine falcon talons tangled in discarded face mask. https://www.bbc.com/ news/uk-england-humber-53530961.

BBC (2020b, August 5) McDonald's: 'Face mask' found inside Aldershot store's chicken nugget. https://www.bbc.com/news/uk-england-hampshire-53617762.

BBC Breakfast [@ BBCBreakfast] (2020, July 22) Is single use \#PPE a threat to wildlife? This seagull got trapped in a face mask in Essex. /bbc.in/2ZSenga [Image attached] [Tweet]. Twitter. https:// twitter.com/BBCBreakfast/status/1285968094020677638.

Bown, C.P. (2020, March 26) COVID-19: China's exports of medical supplies provide a ray of hope. Peterson Institute for International Economics. https://www.piie.com/blogs/trade-and-investmentpolicy-watch/covid-19-chinas-exports-medical-supplies-provide-ray-hope.

Butterworth, A., Clegg, I. \& Bass, C. (2012) Untangled. Marine debris: a global picture of the impact on animal welfare and of animal-focused solutions. World Society for the Protection of Animals, London, UK. Retrieved from https://www.resource-recovery.net/sites/default/files/butterworth_et_ al_untangled_animals_2012.pdf.

Canning-Clode, J., Sepúlveda, P., Almeida, S. \& Monteiro, J. (2020) Will COVID-19 containment and treatment measures drive shifts in marine litter pollution? Front. Mar. Sci., 7, 691. DOI:10.3389/ fmars.2020.00691.

Cardona, A.C. (2020, August 4) Miami Beach Environmental Group Finds Dead Fish Tangled in Facemask. Miami New Times. https://www.miaminewtimes.com/news/environmental-groupfinds-masks-gloves-and-ppe-littering-miami-beach-11677032.

CGTN (2021, January 13) From marine life to birds, wildlife faces threat from masks. [Video]. YouTube. https://www.youtube.com/watch?v=kcCCD6DJWVw.

Chen, K., Wang, M., Huang, C., Kinney, P.L. \& Anastas, P.T. (2020) Air pollution reduction and mortality benefit during the COVID-19 outbreak in China. Lancet Planet. Health, 4, e210-e212. DOI:10.1016/S2542-5196(20)30107-8.

Clean this beach up (@cleanthisbeachup) (2020, July 31) WARNING! PPE SAVES HUMAN LIVES, BUT PUTS MARINE LIFE IN DANGER! (We found this guy tangled up and $@$ today at Picnic [Video] [Photograph]. Instagram. https://www.instagram.com/p/CDUileCAKN6/).

Defina, M. (2020, August 5) Press Release: ARL, MDAR, MVMA reminds public to properly dispose $P P E$. Animal Rescue League of Boston. https://www.arlboston.org/press-release-arl-mdar-mvmareminds-public-to-properly-dispose-ppe/.

Denisuk, S. (2020, April 23) DO NOT THROW AWAY YOUR MASKS OR GLOVES ON THE GROUND. This bird is innocent victims of the corona 19 [Image attached] [Status update]. Facebook. https://www.facebook.com/fraservalleybackroads/posts/666772167389375.

Dutheil, F., Baker, J.S. \& Navel, V. (2020) COVID-19 as a factor influencing air pollution? Environ. Pollut., 263, 114466. DOI:10.1016/j.envpol.2020.114466.

Egelopvang het Stekeltje (2020, October 23) We moeten ons beschermen tegen Covid 19 oa. door het dragen van een mondkapje. Maar wil iedereen na gebruik de elastiekjes. 
[Image attached] [Status update]. Facebook. https://www.facebook.com/permalink.php?story_ fbid=740070110055903\&id=302580257138226.

Fadare, O.O. \& Okoffo, E.D. (2020) Covid-19 face masks: a potential source of microplastic fibers in the environment. Sci. Total Environ., 737, 140279. DOI:10.1016/j.scitotenv.2020.140279.

Getty Images (2020, October 30) Malaysia-health-virus-animal. https://www.gettyimages.co. uk/detail/news-photo/macaque-monkey-attempts-to-eat-a-face-mask-used-as-a-news-photo/ 1229355057.

Groot, D. (2020, July 9) Mondkapjes en plastic handschoenen: een zeer klein zwerfafvalprobleem. [Image attached] [Post]. LinkedIn. https://www.linkedin.com/pulse/mondkapjes-en-plastichandschoenen-een-zeer-klein-dirk-groot/.

Hiemstra, A.F., Gravendeel, B. \& Schilthuizen, M. (subm.) Birds using artificial plants as nesting material. Behaviour.

Jagiello, Z., Dylewski, Ł., Tobolka, M. \& Aguirre, J.I. (2019) Life in a polluted world: a global review of anthropogenic materials in bird nests. Environ. Pollut., 251, 717-722. DOI:10.1016/j.envpol. 2019.05.028.

John Hopkins University and Medicine (2021, January) Dashboard by the Center for Systems Science and Engineering (CSSE) at Johns Hopkins University (JHU). https://coronavirus.jhu.edu/ map.html.

Kassam, A. (2020, June 8) 'More masks than jellyfish': coronavirus waste ends up in ocean. The Guardian. https://www.theguardian.com/environment/2020/jun/08/more-masks-thanjellyfish-coronavirus-waste-ends-up-in-ocean.

Kaur, J. (2020, November 24) COVID-19: discarded face masks posing deadly risk to dogs and other animals. Sky news. https://news.sky.com/story/covid-19-discarded-face-masks-posingdeadly-risk-to-dogs-and-other-animals-12140467.

Klein, J. (2020, August 7) Seagulls fight over face mask on Weymouth beach. Dorset Echo. https:// www.dorsetecho.co.uk/news/18634193.seagulls-fight-face-mask-weymouth-beach/.

Kompanje, E.J.O. (2021, January 4) Gevederde coronadoden. https://kompanje.org/2021/01/03/ gevederde-coronadoden/.

Kuhn, S. \& van Franeker, J.A. (2020) Quantitative overview of marine debris ingested by marine megafauna. Mar. Pollut. Bull., 151, 110858. DOI:10.1016/j.marpolbul.2019.110858.

Laist, D.W. (1997) Impacts of marine debris: entanglement of marine life in marine debris including a comprehensive list of species with entanglement and ingestion records. In: J.M. Coe \& D.B. Rogers (Eds) Marine Debris. Springer Series on Environmental Management, pp. 99-139. Springer, New York, NY, USA. DOI:10.1007/978-1-4613-8486-1_10.

Leighton, G.R.M., Hugo, P.S., Roulin, A. \& Amar, A. (2016) Just Google it: assessing the use of Google Images to describe geographical variation in visible traits of organisms. Meth. Ecol. Evol., 7, 1060-1070. DOI:10.1111/2041-210X.12562.

Matthews, C. (2020, July 21) Volunteers asked to record PPE during this year's Great British Beach Clean. Discover Wildlife. https://www.discoverwildlife.com/news/volunteers-asked-torecord-ppe-during-this-years-great-british-beach-clean/.

Ministerie van Economische Zaken (2015, October 23) Besluit van de Staatssecretaris van Economische Zaken van 15 oktober 2015, DGAN-PDJNG / 15129301, houdende vaststelling van geactualiseerde Rode lijsten flora en fauna. Staatscourant van het Koninkrijk der Nederlanden. https:// zoek.officielebekendmakingen.nl/stcrt-2015-36471.html.

Ministerie van Landbouw, Natuur en Voedselkwaliteit (n.d.) Habitatrichtlijn: soort van habitatrichtlijn Bijlage II. Retrieved January 11, 2020 from: https://minlnv.nederlandsesoorten.nl/ content/habitatrichtlijn-soort-van-habitatrichtlijn-bijlage-ii. 
Myllyvirta, L. (2020, February 19) Analysis: coronavirus temporarily reduced China's CO2 emissions by a quarter. Carbon brief. https://www.carbonbrief.org/analysis-coronavirus-has-temporarilyreduced-chinas-co2-emissions-by-a-quarter.

NASA (2020) Airborne nitrogen dioxide plummets over China. https://earthobservatory.nasa.gov/ images/146362/airborne-nitrogen-dioxide-plummets-over-china.

O'Laughlin, F. (2020, April 9) Mass. police warn public that dumping used gloves, masks in parking lots is punishable by $\$ 5 K$ fine. News Boston. https://whdh.com/news/mass-police-warn-publicthat-dumping-used-gloves-masks-in-parking-lots-is-punishable-by-5k-fine/.

Opération Mer Propre (2020a, September 23) “OMP INVESTIGATION” à Martigues. Aucune région ni département ne sont épargnés par les nouveaux déchets liés à la crise sanitaire. [Image attached] [Status update]. Facebook https://www.facebook.com/groups/2596005247293221/ permalink/3035460846680990.

Opération Mer Propre (2020b, July 1) Poulpito [Video]. YouTube. https://www.youtube.com/watch? $\mathrm{v}=$-coGPI0GIdI.

OSPAR (2010) Guideline for monitoring marine litter on the beaches in the OSPAR Maritime Area. Edition 1.0. OSPAR Commission, London, UK. Retrieved from https://www.ospar.org/documents? $\mathrm{v}=7260$.

Pakdel, A. (2020, May 29) Although we must prevent Corona viruses disease, we must also take care of the environment. Cartoon by Alireza Pakdel. [Image attached] [Post]. Instagram. https://www. instagram.com/p/CAxH0aAFgCz/.

Penza, N. (2020, September 22) Penguin found dead on Brazilian beach after swallowing entire face mask during voyage from Patagonia, autopsy shows. MailOnline. https://www.dailymail.co. uk/news/article-8759717/Penguin-dead-Brazilian-beach-swallowing-entire-face-mask-autopsyshows.html.

Prata, J.C., Silva, A.L.P., Walker, T.R., Duarte, A.C. \& Rocha-Santos, T. (2020) COVID-19 pandemic repercussions on the use and management of plastics. Environ. Sci. Technol., 54, 7760-7765. DOI:10.1021/acs.est.0c02178.

Rambonnet, L., Vink, S.C., Land-Zandstra, A.M. \& Bosker, T. (2019) Making citizen science count: best practices and challenges of citizen science projects on plastics in aquatic environments. Mar. Pollut. Bull., 145, 271-277. DOI:10.1016/j.marpolbul.2019.05.056.

Rambonnet, L., Hiemstra, A.-F., Siepman, D. \& van Emmerik, T. (2020, September 8) Plastic Spotter: successes and challenges of co-creating a local citizen science project on plastic pollution. Zenodo. DOI:10.5281/zenodo.4100587.

Regen, C. (2018, August 30) Shocking image shows fish became trapped inside a plastic glove in latest haunting pic highlighting the scourge of plastic in our seas. The Sun. https://www.thesun. co.uk/news/7133162/fish-trapped-plastic-glove-sea-pollution/.

Reuters (2020, August 11) A seagull carries a protective face mask at the port of Dover, Britain, August 11, 2020. REUTERS/Peter Nicholls. https://pictures.reuters.com/archive/HEALTHCORONAVIRUS-BRITAIN-ENVIRONMENT-RC2NBI9KIFRP.html.

Riglen, V. (2020, November 6) Great British Beach Clean 2020 results: PPE pollution on the rise on UK's beaches. https://www.mcsuk.org/news/gbbc_2020_results.

Rocha, R., Aziz, S.A., Brook, C.E., Carvalho, W.D., Cooper-Bohannon, R., Frick, W.F., Huang, J.C.-C., Kingston, T., Lopez-Baucells, A., Maas, B., Mathews, F., Medellin, R.A., Olival, K.J., Peel, A.J., Plowright, R.K., Razgour, O., Rebelo, H., Rodrigues, L., Rossiter, S.J., Russo, D., Straka, T.M., Teeling, E.C., Treuer, T., Voigt, C.C. \& Webala, P.W. (2020) Bat conservation and zoonotic disease risk: a research agenda to prevent misguided persecution in the aftermath of COVID-19. Anim. Conserv. DOI:10.1111/acv.12636. 
RSPCA (2020, September 10) 'Snip the straps' off face masks as Great British September Clean launches. https://www.rspca.org.uk/-/news-face-masks-spring-clean.

RSPCA Essex South [@ rspcaessexsth] (2020, July 19) A young gull with a disposable face mask tangled round its legs. As it has been there a while the. [Image attached] [Tweet]. Twitter. https:// twitter.com/rspcaessexsth/status/1284793897319882752.

Ryan, P.G. (2018) Entanglement of birds in plastics and other synthetic materials. Mar. Pollut. Bull., 135, 159-164. DOI:10.1016/j.marpolbul.2018.06.057.

Schweitzer, J.-P., Petsinaris, F. \& Gionfra, C. (2018) A Study by Zero Waste Europe and Friends of the Earth Europe for the Rethink Plastic Alliance. Justifying Plastic Pollution: How Life Cycle Assessments Are Misused in Food Packaging Policy. Institute for European Environmental Policy (IEEP), Brussels, Belgium.

Shereen, M.A., Khan, S., Kazmi, A., Bashir, N. \& Siddique, R. (2020) COVID-19 infection: origin, transmission, and characteristics of human coronaviruses. J. Adv. Res., 24, 91-98. DOI:10.1016/j. jare.2020.03.005.

Silva, A.L.P., Prata, J.C., Walker, T.R., Campos, D., Duarte, A.C., Soares, A.M.V.M., Barcelò, D. \& Rocha-Santos, T. (2020) Rethinking and optimising plastic waste management under COVID-19 pandemic: policy solutions based on redesign and reduction of single-use plastics and personal protective equipment. Sci. Total Environ., 742, 140565. DOI:10.1016/j.scitotenv.2020.140565.

Silva, A.L.P., Prata, J.C., Walker, T.R., Duarte, A.C., Ouyang, W., Barcelò, D. \& Rocha-Santos, T. (2021) Increased plastic pollution due to Covid-19 pandemic: challenges and recommendations. Chem. Eng. J., 405, 126683. DOI:10.1016/j.cej.2020.126683.

Simmons, A. (2020, September 1) Tragic photo shows seagull carrying discarded face mask on Weston-super-Mare seafront. Burnham and Highbridge Weekly News. https://www. burnhamandhighbridgeweeklynews.co.uk/news/18689035.tragic-photo-shows-seagull-carryingdiscarded-face-mask-weston-super-mare-seafront/.

Stachowitsch, M. (2019) The Beachcomber's Guide to Marine Debris. Springer International Publishing, Cham, Switzerland.

Szulkin, M. [@MartaSzulkin] (2020, April 14) \#covid19 precaution measures are entering the realm of avian reproduction... here a plastic glove used by sparrows to build a nest... [Image attached] [Tweet]. Twitter. https://twitter.com/MartaSzulkin/status/1250172647587098625.

Tasseron, P., Zinsmeister, H., Rambonnet, L., Hiemstra, A.-F., Siepman, D. \& van Emmerik, T. (2020) Plastic hotspot mapping in urban water systems. Geosciences, 10, 342. DOI:10.3390/ geosciences 10090342 .

Toliver, Z. (2020, September 20) Don't let your masks harm animals! How to dispose of them responsibly. PETA. https://www.peta.org/blog/face-masks-litter-harms-animals/.

UCL Plastic Waste Innovation Hub (2020) The environmental dangers of employing single-use face masks as part of a COVID-19 exit strategy. https://d2zly2hmrfvxc0.cloudfront.net/Covid19Masks-Plastic-Waste-Policy-Briefing.final.pdf.

University of Glasgow (2020, September 5) Kobe was out for an afternoon walk when he spotted a discarded face mask and wolfed it down. Luckily, his [Image attached] [Status update]. Facebook. https://www.facebook.com/glasgowsmallanimalhospital/posts/3241705115866449.

van Aarsen, A. (2018, August 9) 22ste vissoort in Leiden 'slecht nieuws'. Leidsch Dagblad. https:// www.leidschdagblad.nl/cnt/dmf20180926_53448204/22ste-vissoort-in-leiden-slecht-nieuws

van Doremalen, N., Bushmaker, T., Morris, D.H., Holbrook, M.G., Gamble, A., Williamson, B.N., Tamin, A., Harcourt, J.L., Thornburg, N.J., Gerber, S.I., Lloyd-Smith, J.O., de Wit, E. \& Munster, V.J. (2020) Aerosol and surface stability of SARS-CoV-2 as compared with SARS-CoV-1. N. Engl. J. Med., 382, 1564-1567. DOI:10.1056/NEJMc2004973. 
van Emmerik, T. \& Schwarz, A. (2020) Plastic debris in rivers. WIREs Water, 7, e1398. DOI:10.1002/ wat2.1398.

van Gerwen, J. (2021, January 3) Van mondkap naar 'lampenkap' Het is 03.00 uur in de nacht van zaterdag op zondag. Ik ben moe en klaarwakker [Image attached] [Status update]. Facebook. https://www.facebook.com/janneke.vg.9/posts/2149505295184089.

van Otterlo, M. (2020, September 26) Kutmondkapjes! Of in elk geval de mensen die ze zo achter laten. Sorry, maar wil iedereen die de eenmalige mondkapjes [Image attached] [Status update]. Facebook. https://www.facebook.com/mirjam.vanotterlo.3/posts/10214515073505376.

Verkade, A. (2018) Drie jaar vissenmonitoring in Leiden. RAVON, 20, 9-11.

World Health Organization (2020, March 11) WHO Director-General's opening remarks at the media briefing on COVID-19. https://www.who.int/director-general/speeches/detail/who-directorgeneral-s-opening-remarks-at-the-media-briefing-on-covid-19---11-march-2020.

wwfitaly [@wwfitaly] (2020, September 14) Finalmente si torna a \#scuola. Per circa 7 milioni di \#studenti della scuola pubblica italiana tra i 6 e $i$ [Image attached] [Tweet]. Twitter. https://twitter. com/WWFitalia/status/1305516307056676865. 